\title{
KICKBOXING, BREAKDANCE AND POP MUSIC VERSUS WRESTLING, ROUND DANCE AND FOLK MUSIC? POPULAR CULTURE IN BURYATIA TODAY
}

\author{
Stefan Krist
}

\begin{abstract}
This paper deals with the peculiarities and recent developments of popular culture in general and sports competitions, dance and music, particularly in Buryatia and other regions of significant Buryat population. Based mainly on the author's own observations it is shown how the ongoing societal changes are reflected in the activities of sportspeople, dancers and musicians. All of them are characterised by both traditional and re-traditionalised elements as well as by processes of modernisation. It is shown that these at first sight contradictory features are in fact most often converging. Thus, in Buryatia today, mixing styles can be identified as one of the main and most typical characteristics of sports, dance, and music.
\end{abstract}

Key words: Buryatia, cultural convergence, music, popular culture, sport competitions

This article is essentially an ethnographic report, based almost entirely on the author's personal observations. It will give a brief survey of the activities in which the majority of young people in Buryatia are engaged, as young people in Buryatia - as elsewhere - love sports, dancing, and music. I will mainly focus on the popular Buryat summer festivity Surkharban, which has attracted my interest since the very beginning of my research in the mid-1990s in the Buryat Republic and other regions of significant Buryat population. As sports events are central in celebrating the festivity, though music and dance are also important, they provide an ideal opportunity to analyse popular culture in general. In addition, I will discuss other competitions, sports activities, major holidays and public activities of the young people which have been subjects of my field observations and research. Thus the article gives an insight into the widespread and most popular leisure activities of young people in Buryatia.

Surkharban is an ancient Buriat-Mongolian festivity of sports games and comprises wrestling, horse racing and archery contests, which possibly root in 
shamanic cults. This festivity has been very popular among the Buryats at all times and in all political and economic situations, under the Tsarist rule as well as during the Soviet period and also in modern times. The various societal systems have strongly influenced and changed the nature of the festivity. Thus the different ways in which the festivity was held reflected the different forms of the Buryat society. One can see societal changes and developments in the festivity's practices even today.

In previous studies the aspects of change and development which the Buryat festivity underwent in the Tsarist times and during the Soviet period have been described and analysed (Krist \& Lang 2003; Krist 2004, 2006; Dugarova 2004; Krist \& Kabunova 2006). In this article, the main focus is on the process of re-traditionalising it, step by step, after the collapse of the Soviet system. It has been mentioned that this process of re-traditionalisation is accompanied, or contrasted, in many respects by modernisation, which can be called 'westernisation' (Krist 2004). In this article, I will concentrate on these ambivalent developments and will pose a number of questions which might provide clues to the discussion of how people in Buryatia in general, and youth in particular, deal with this dichotomy of tradition and modernity.

\section{NEW SPORTS VERSUS ANCIENT GAMES}

In Buryatia today, the centuries-old traditional Buryat sports competitions such as wrestling, horse racing, and archery stand in contrast to a growing number of newly imported forms of sport. Some of these were introduced in Buryatia already more than half a century ago: for example, ball games such as volleyball, basketball, and soccer, but also track-and-field disciplines, which both gained popularity first among Russians but are today also very popular among Buryats. Already since the Soviet times, a volleyball tournament is an additional part of the program of almost all Surkharban festivities, as are soccer competitions between the teams of different villages or institutions (e.g., of schools, hospitals, administrations, etc.). Adding these new sports to the event programs was and is widely accepted by both Russians and Buryats. People do not think that the traditional "three games of men" are in any way threatened by these additional sports, but, in fact, regard them as enriching the festivity. 


\section{SHOW VERSUS COMPETITION}

Another sports discipline which appeared in Buryatia already in the 1930s is dumbbell lifting. Competitions in this strength sport became part of virtually all Surkharban festivities in the post-war decades. However, at the Republic's main Surkharban festivity held in 2004 in Ulan-Ude, the capital of Buryatia, dumbbell lifters performed a nicely arranged dumbbell juggle show, a dumbbell "ballet", as part of the festivity's opening ceremony. ${ }^{1}$ With this show and ballet, the dumbbell lifters of Buryatia followed the global trend of incorporating elements of show and pure entertainment into the field of sports.

During the last few years the Surkharban festivities have drifted significantly towards becoming major show events. Regardless of this development, the obeying of all the rules in the competition is still important. Thus the increase in the number of show elements has not lead to any significant changes in the original competitions, and applies mainly to the entertainment programs of the festivities.

\section{KICKBOXING VERSUS TRADITIONAL WRESTLING}

The development described above can be illustrated by two following examples. At the republic's Surkharban games in 2004, part of the opening ceremony program was a show of taekwondo fighters, who demonstrated their impressive skills, and in 2005 the audience was entertained by karate and wushu shows of young boys and girls.

It is not by pure chance that of all different sports these particular disciplines play such a prominent role at Buryatia's biggest annual sports event. Taekwondo and other martial arts, such as kickboxing, judo, karate, wushu (better known as kung fu in the Western world), and sambo (an abbreviation of Russian samozashchita bez oruzhiya, 'self-defence without weapons') became quite recently and very rapidly popular in Buryatia. Most of the clubs, organisations and federations of these disciplines of martial arts were founded in Buryatia quite recently: for example, Judo Federation in 1994, Wushu Federation in 2002 and Karate Club only in 2003. Nonetheless, all these organisations have hundreds of members and the best of them have already won Russian, European and even World Championships. ${ }^{2}$ The same could also be said of two newly introduced strength sports - arm-wrestling and power-lifting. In these disciplines, sportsmen and sportswomen from Buryatia have performed 
very successfully at an international level. ${ }^{3}$ Even though there are other kinds of sports, which have recently gained popularity (e.g., the first tennis court of international standard and a go-cart racing track were opened in Ulan-Ude in 2004), the popularity of martial arts and strength sports in Buryatia during the last few years is quite remarkable. It has to be stressed, however, that this has not lead to a decrease in the popularity of the Buryat's most favourite sports freestyle wrestling, which follows both the national Buryat and international rules, is still, especially in rural regions, the most popularly practiced sports activity among young males. The marked preference of the people of Buryatia for martial arts and strength sports is indeed remarkable enough to let both traditional and newly introduced sports to flourish.

\section{WOMEN'S EMANCIPATION VERSUS MALE DOMINATION}

As in other parts of the world, freestyle wrestling is no longer purely a male domain in Buryatia. According to the 2003 statistics of the Buryat Republic from 31 December, of the 7,411 people who were practicing freestyle wrestling 570 were women. The figures for most other martial arts as well as for the strength sports, such as dumbbell lifting, power-lifting and arm-wrestling, show even a larger number of women participation. Surprisingly, the highest percentage of female participation can be seen in one of the three traditional games of men - namely, archery. The statistics show that 42 per cent of all archers are female. ${ }^{4}$ Among those who compete at a high level, women are even in majority. Among the sporting activities which have recently gained popularity in Buryatia, apart from those already mentioned, various other kinds of shooting sports are practised: for instance, shooting with small bore rifles, air rifles and airguns, and crossbow-shooting. Again, quite a large number of female shooters can be seen at these shooting ranges.

Thus, contrary to some tendencies to re-traditionalise and even to rename the festivity of Surkharban - a term which literally means 'archery' but was introduced as a collective name for the festivity during the Soviet times - and reinstate its former name Eryn Gurban Naadan, or ‘The Three Games of Men', women have considerably gained ground in all sporting disciplines, even the traditionally male-dominated ones. 


\section{MODERN LIFESTYLE VERSUS TRADITIONAL VALUES}

For centuries it has been a tradition at Buryat festivities to organise competitions in sports and other fields. A traditional competition was held for singers of Buryat epic poems. Today, attempts have been made to revive these or similar skills. The following short report may serve as an example.

The members of the Khongodor tribe live scattered and far from each other in three districts of the Buryat Republic, in the Irkutsk Region, and northern Mongolia. At their meeting in June 2004 in the village Sanaga in the southwestern part of the republic, competitions which followed the traditionally required nine skills of a Buryat man - woodwork, horseshoe forging, whip plaiting, and others, and also singing morinoj solo, traditional praise for horses were organised in addition to the usual three sporting competitions.

On the same occasion a pageant called Khongoodoroj Dangina, which translates as the 'Beauty Queen of the Khongodors' was held. At the Surkharban games of the Ekhirit-Bulagatskii District in the village Kapsal, a similar competition for young women aged from 18 to 25 was called simply Konkurs "Miss Ekhirit" ('Beauty Pageant "Miss Ekhirit"). ${ }^{5}$ Tasks given to the participants of these contests ranged from drawing self-portraits, telling their life stories in the style of a Buryat epic, singing (Buryat folk songs in Sanaga village, Russian pop songs in Kapsal village), dancing (folk dances in Sanaga, ballroom dances in Kapsal) to answering the question, what they would do if they were deputy of parliament in their district, and even cooking domashnaia lapsha (homemade noodle soup). Thus, these contests represent something in-between the traditional Buryat competitive culture, reflecting and strengthening traditional values, and modern entertainment shows, and reflecting Western urban lifestyle.

The program of the 2004 Ulan-Ude City Festival (den' goroda) - an annually organised anniversary festivity of Ulan-Ude, Buryatia's capital - included a competition of hairstylists and a fashion show called avangardnaia moda ('avant-garde fashion'), at which young Russian and Buryat models presented about a dozen beautiful dresses created by the most talented local fashion designers. All these dresses represented a mixed style: trendy European couture combined with typically Asian elements, such as, for example, the designers' particular liking to colourful silk fabrics. 


\section{RUSSIAN PARTICIPATION VERSUS RE-BURYATISATION}

At the same festival a competition in singing popular songs was held. The winner was chosen according to the audience's applause. Only one contestant sang a Buryat song, but this singer also ended up winning the competition. Curiously, the audience was not overwhelmingly Buryat, but was made up of Russians and Buryats in the same relation as the city's population: approximately two-thirds was Russian, and one-third was Buryat. This case may serve as one example of the general mutual respect between the local Russians and Buryats. Sometimes both even hold in esteem, at least to a certain degree, the culture of the other ethnic group, for instance, when speaking about their conduct in public.

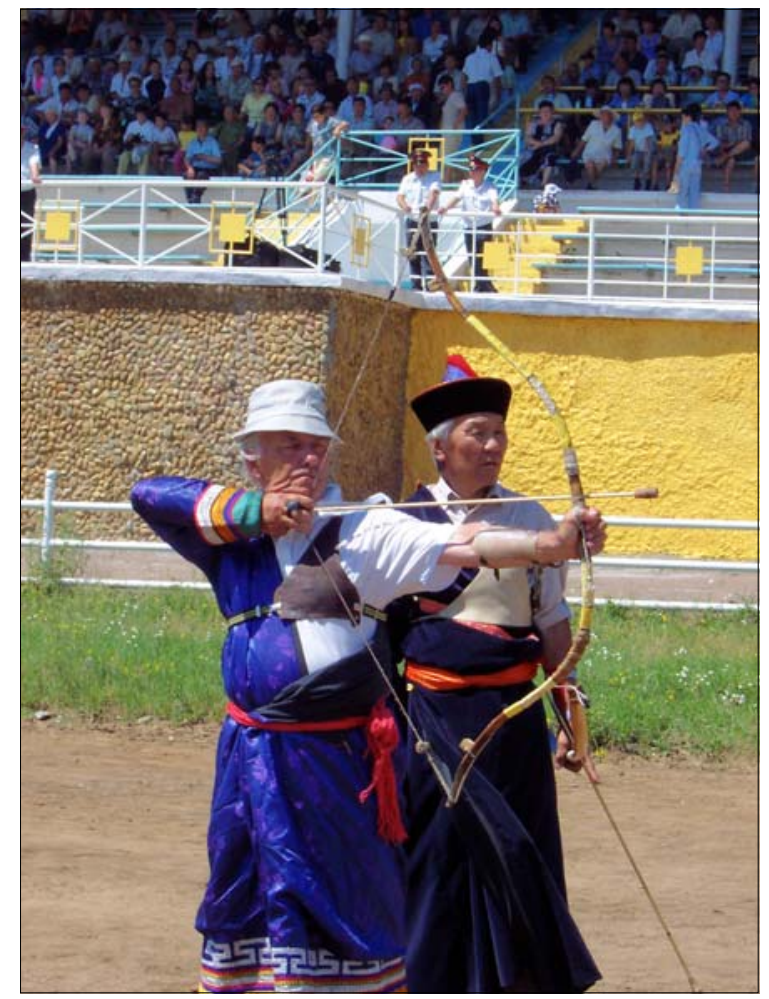

Photo 1. Russian archer competing with a Buryat, both wearing traditional Buryat costumes. The 2004 Sukharban in the Buryat Republic. Photo by Stefan Krist. 
Sports in Buryatia are no exception to this. I have never noticed ethnic tension or open hostilities among the sportspeople participating at the many sporting events in Buryatia and the two Buryat autonomous districts in the Irkutsk and Chita regions. All kinds of sports are practiced today by both ethnic groups, although some of them are, no doubt, more popular in only one group. For example, lapta, the Russian variant of baseball, and also soccer are much more popular among Russians, whereas archery and wrestling are preferred by Buryats. Russians have adopted even these "traditionally Buryat" disciplines, and are often quite successful in these. For instance, in 2004 Russian wrestler Oleg Bolonev won the wrestling tournament which was part of the Buryat New Year's celebration. Dumbbell lifters, also mainly Russians, had already decades ago incorporated the discipline among all the Surkharban games and it is acknowledged as the festivity's fourth discipline. Only at the explicitly re-traditionalised sports festivals in the Buddhist monasteries the "pure" Buryat form with only three games of men has been re-established. But even there, Russian wrestlers, archers and jockeys take part in the competitions, regardless of whether they are Buddhists or not. Briefly put, retraditionalising the Buryat sporting practices does not limit the participation of Russians, quite the opposite.

\section{BREAKDANCE VERSUS ROUND DANCE}

In former times, during almost the entire day yokhor, traditional Buryat round dances, were danced at every Buryat festivity. Like the games themselves, the round dances were the community's symbolic gifts or offerings to spirits and deities. At the Eryn Gurban Naadan in 2003 in the Ivolginsk Buddhist Monastery, one of such purposely re-traditionalised sports festivities was revived. A group of women wearing traditional Buryat costumes performed round dances for hours at the event. A year later, in 2004, the event no longer took place. Perhaps it was due to bad weather, but the heavy rain did not hinder the usual competing of sportspeople or cancel the long opening concert of traditional folk tunes, sung in Buryat but using pop and Latin-American rhythms, by Buryat artists Nonna and Zorigto Togochiev. The audience, among whom was also the Khambo Lama, the highest Buddhist priest of Buryatia and whole Russia, greatly enjoyed the show. This leaves the impression that in Buryatia today, especially among the youth, dances other than the traditional yokhor are popular, and this applies both to participating in dancing and watching shows. At the above-mentioned annual city festivals of Ulan-Ude even really popular groups of breakdancers take the stage. 
There are several excellent Buryat dance companies, featured in the program of the Surkharban games as well as the den' goroda, which stage wonderful and highly artistic shows entailing at least an element of a traditional Buryat round dance.

\section{POP MUSIC VERSUS FOLK MUSIC}

Singing in mixed style, like the Togochievs in Ivolginsk, has become generally popular among Buryat singers. Other examples are the well-known singers Medegma Dorzhieva, Badma Khanda Ayusheeva (who in 2001 released a CD on which traditionally arranged songs alternate with songs produced in pop style, but all of them are sung in Buryat), Inna Shagnaeva, Bulat Gomboev (who both sing Buryat as well as Russian songs), Khazhidma Ayurzhanaeva, Namgar Lkhasaranova, and others.

Namgar Lkhasaranova comes from the Aginsk Buryat Autonomous District but has been living in Moscow for about ten years and is already wellknown on the international music scene. Her first Ulan-Ude concert in years in July 2004 was sold out and received standing ovations. Her band consisted

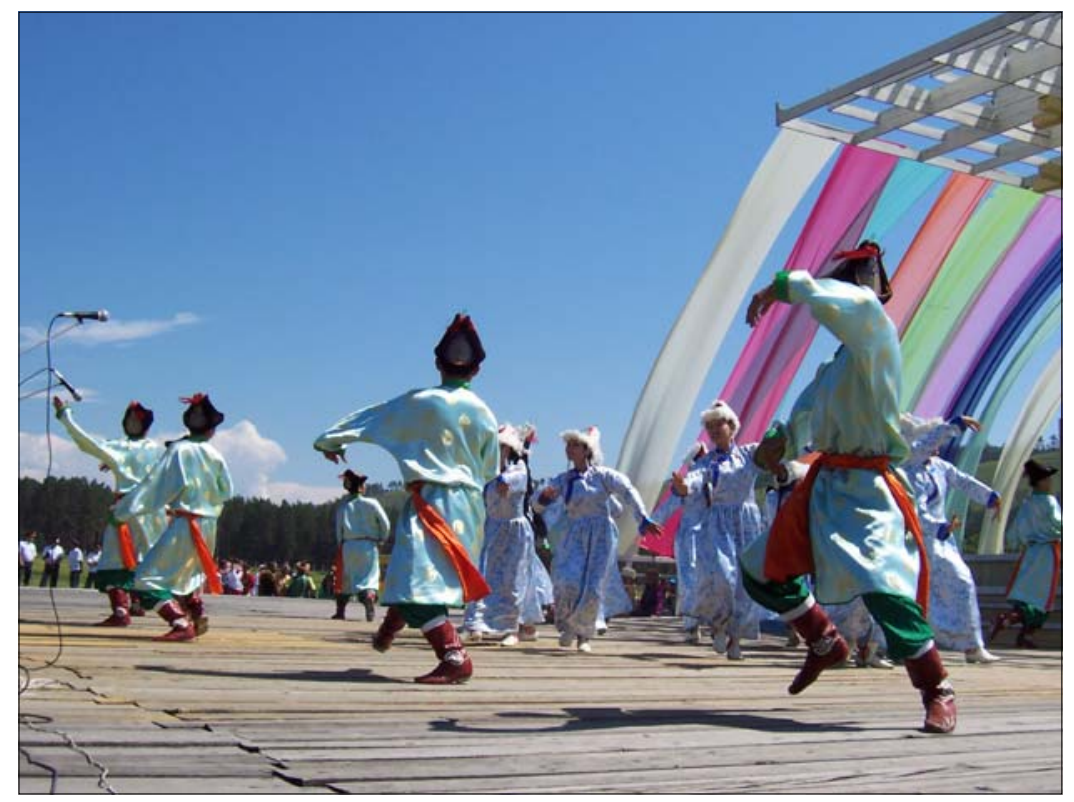

Photo 2. A Buryat folk dance ensemble on stage. The 2004 Sukharban in the Buryat Republic. Photo by Stefan Krist. 
of two Mongolian and two Russian musicians. The Mongolians played traditional instruments morin khuur and yataga, ${ }^{6}$ the Russians (one of them Namgar's husband) played bass guitar and drums. Even so, the band appeared on stage only in the second part of the concert, when traditionally arranged Buryat songs were performed, whereas the first part included pop and disco songs which Namgar performed alone, accompanied only by loud pre-recorded synthesiser playbacks. It is worth mentioning that when Namgar performed in Paris in 2006, where I had the next opportunity to attend one of her concerts, the program consisted almost entirely of traditional songs. This is not only a fine example of the ability of Buryat musicians to switch styles and successfully adapt to their audiences' taste and expectations, but also quite clearly reveals the mainstream music taste in Buryatia today: It is actually a synthesis (or at least an alternation) of traditional and modern styles that people demand. ${ }^{7}$

\section{BUDDHISM VERSUS STATE POWER}

Mixing styles has also occurred at sports events: In 2003, the Surkharban games of the Buryat community in the town of Irkutsk was sponsored by Edinaia Rossiia, the political party of Vladimir Putin, whereas the Surkharban games of the Ekhirit-Bulagatski District in the Kapsal village in 2004 was sponsored by DPR Yabloko, the party of Grigori Yavlinskii, then one of Putin's few remaining opponents. The interference of political parties or, in more general terms, of politics into sports in this openly declared form is a new phenomenon. Commercial sponsoring could already be observed for several years (Krist 2004), but the variety of companies which sponsor the Surkharbans, has increased. Among these there are local companies, such as Buriatzoloto (Buryatia's gold mining company), Buriatmyasprom (meat processing company), Baikalfarm (vodka distillery), and others as well as major corporations like Sakhayuvelir (Yakutia's jewellery manufacturing and trading company), Pepsi, and Yukos. The latter supports many competitions and events in Buryatia, which can be easily understood as the company's effort to get support from the local people for their project to build an oil pipeline around Lake Baikal, partly through nature reserves, which understandably is a heavily disputed project.

In addition to political parties and commercial enterprises, the third important institution in the Buryat society - the Buddhist clergy - is trying to exploit the Buryats' enthusiasm for sports to increase its influence. Inaugurations of new Buddhist institutions are already regularly accompanied by three competitions. In 2004, at the Eryn Gurban Naadan held in the Ivolginsk mon- 
astery, the prizes for the winners of the competitions were more than twice as high as at the state's Surkharban festivity. Lama priests handed over 21,000 rubles to every winner, an amount that equalled four monthly salaries of a teacher. But a good share of this money was donated by commercial companies and state representatives (Mikhailov 2004), who were also present, sitting to the left and to the right of the Khambo Lama. In short, sports in Buryatia are a hot spot for the struggle for influence and power between all the society's important political, commercial and religious institutions. This competition is conducted in a peaceful manner, though definitely not always according to the rules of fair play, and, what counts here, to the benefit of Buryatia's sportspeople and artists, because it is this process that ensures the financing of sports and festivals. ${ }^{8}$

\section{CONCLUSION}

The questions raised here for the purpose of discussing the manifold tendencies and developments in sports, dance and music in Buryatia in the last years deliberately suggest contradictions in these, but this is, in fact, not the case. The whole area of Buryat sports and popular culture can be described as a convergence, combination, or intertwining of all these phenomena and developments rather than as being contradictory. Kickboxing, breakdance and pop music complement wrestling, round dance and folk music. Women's emancipation and modern lifestyle complement male domination and traditional values. State power and Russian participation complement Buddhism and re-Buryatisation.

Buryatia's society is ethnically and culturally mixed and diverse. Furthermore, in post-Soviet times it has become an open, modern and pluralistic society in almost every respect. This and the still ongoing major changes in the whole society certainly find their expression in areas of popular culture like sports, dance, and music. Thus, young people, who represent the majority in these areas, are directly involved in these processes of societal changes and not only in a passive way but also have active roles, as the many examples presented in this article have proved. 


\section{NOTES}

${ }^{1}$ By the way, half of the members of that ballet company were young females. (Further on female participation in sports in Buryatia see paragraph "Women's emancipation versus male domination.")

${ }^{2}$ Bair Ulakhinov, World Champion in professional kickboxing, and Sergei Dorzhitarov, who became the two-time Sambo World Champion.

3 Maksim Maksimov has twice won the European and the World Championships in arm-wrestling.

${ }^{4}$ All statistical data according to a survey carried out by the State Committee of Youth Affairs, Physical Education and Sports of the Buryat Republic for the use of district administrations and federal authorities. The author owns a private photocopy.

5 Ekhirit is the name of the largest Buryat tribe in the Irkutsk Region.

6 Morin khuur is a type of violin, a string instrument with a rectangular corpus and two strings played with a bow. Instead of a violin's scroll it has a carved horse head. Yataga is a large Buryat-Mongolian zither.

7 The examples of Buryat musicians and their audience presented here are not unique: Aimar Ventsel describes quite similar patterns and phenomena on the music scene of the Sakha Republic (Yakutia) (Ventsel 2004, 2006).

${ }^{8}$ A similar situation is described by Aimar Ventsel about the Sakha Republic (Yakutia), where Sakha musicians are almost entirely dependent on the financial and logistic support from politicians, state officials, businessmen and quite often also from (semi)criminals. Sometimes all these may be embodied by the same person. (Ventsel 2004, 2006)

\section{REFERENCES}

Dugarova, Radzhana D. 2004. Tradicionnyi sportivnyi prazdnik "eryn turban naaldan" ("tri igrishcha muzhei") i ego mesto v kul'ture buriat. [The traditional sports festivity Eryn gurban naadan ('Three games of men') and its position in Buryat culture.] PHD dissertation. Ulan-Ude.

Krist, Stefan \& Lang, Maria-Katharina 2003. Surkharban Depicted: An Analytical Double View. In: A. Sárközi \& A. Rákos (eds.) Altaica Budapestinensia MMII. Proceedings of the 45th Permanent International Altaistic Conference (PIAC) Budapest, Hungary, June 23-28. Budapest: Hungarian Academy of Sciences, pp. 199-210.

Krist, Stefan 2004. Where Going Back is a Step Forward: The Re-Traditionalising of Sport Games in Post-Soviet Buriatia. Sibirica. Vol. 4, No. 1, pp. 104-115. 
Krist, Stefan \& Kabunova, A. 2006. O buriatskom sportivnom prazdnike Surkharban kak siuzhete izobrazitel'nogo iskusstva. [About the Buryat sport event Surkharban as a subject of visual arts.] Buriaty v kontekste sovremennykh etnokul'turnykh i etnosotsial'nykh protsessov. Traditsionnaia kul'tura, narodnoe iskusstvo i natsional'nye vidy sporta buriat $v$ usloviiakh polietnichnosti. [The Buryats in the context of modern ethnocultural and ethnosocial processes. The Buryat traditional culture, folk art and national sports in multiethnic community.] Volume 1. UlanUde: Izdatel'sko-poligraficheskii kompleks FGOU VPO VSGAKI, pp. 381-394.

Krist, Stefan 2006. A burját "surxarban" ünnep története és jelentősége. [History and importance of the Buriat holiday "surkharban”.] In: Á. Birtalan (ed.) Mongol játékok és versenyek. [Mongolian Games and Competitions.] Budapest: Akademiai kiado, pp. 17-23.

Mikhailov, Oleg 2004. Sostiazaniia pod vsevidiashchim okom bozhestv'. [Competitions under the Omnispective Eye of the Gods.] Inform Polis. No. 30 (617), p. 15.

Ventsel, Aimar 2004. Stars without the Money: Sakha Ethnic Music Business, Upward Mobility and Friendship. Sibirica. Vol. 4, No. 1, pp. 88-103.

Ventsel, Aimar 2006. Sakha Pop Music: A Celebration of Consuming. Anthropology of East Europe Review. Vol. 24, No. 2, pp. 35-43. 